
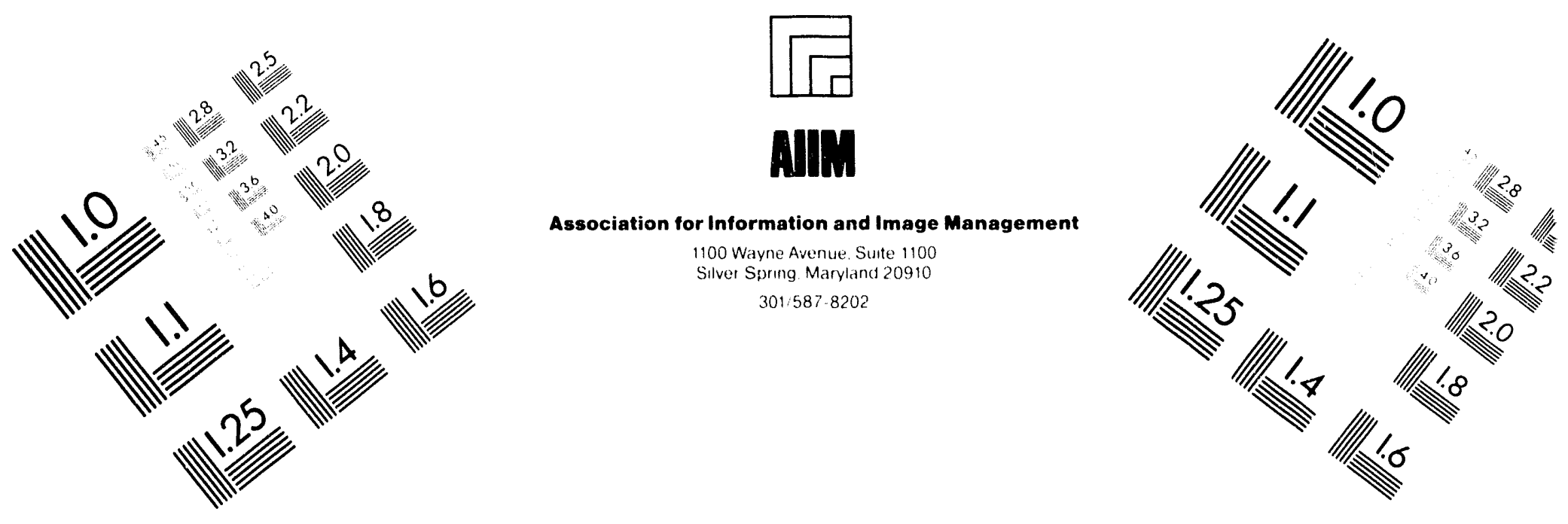

\title{
Centimeter
}

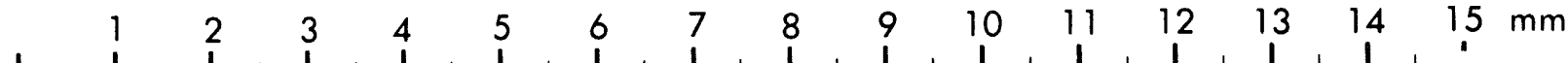

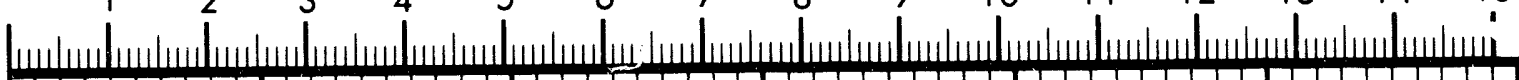

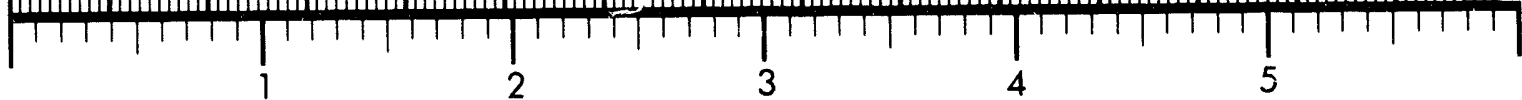
Inches
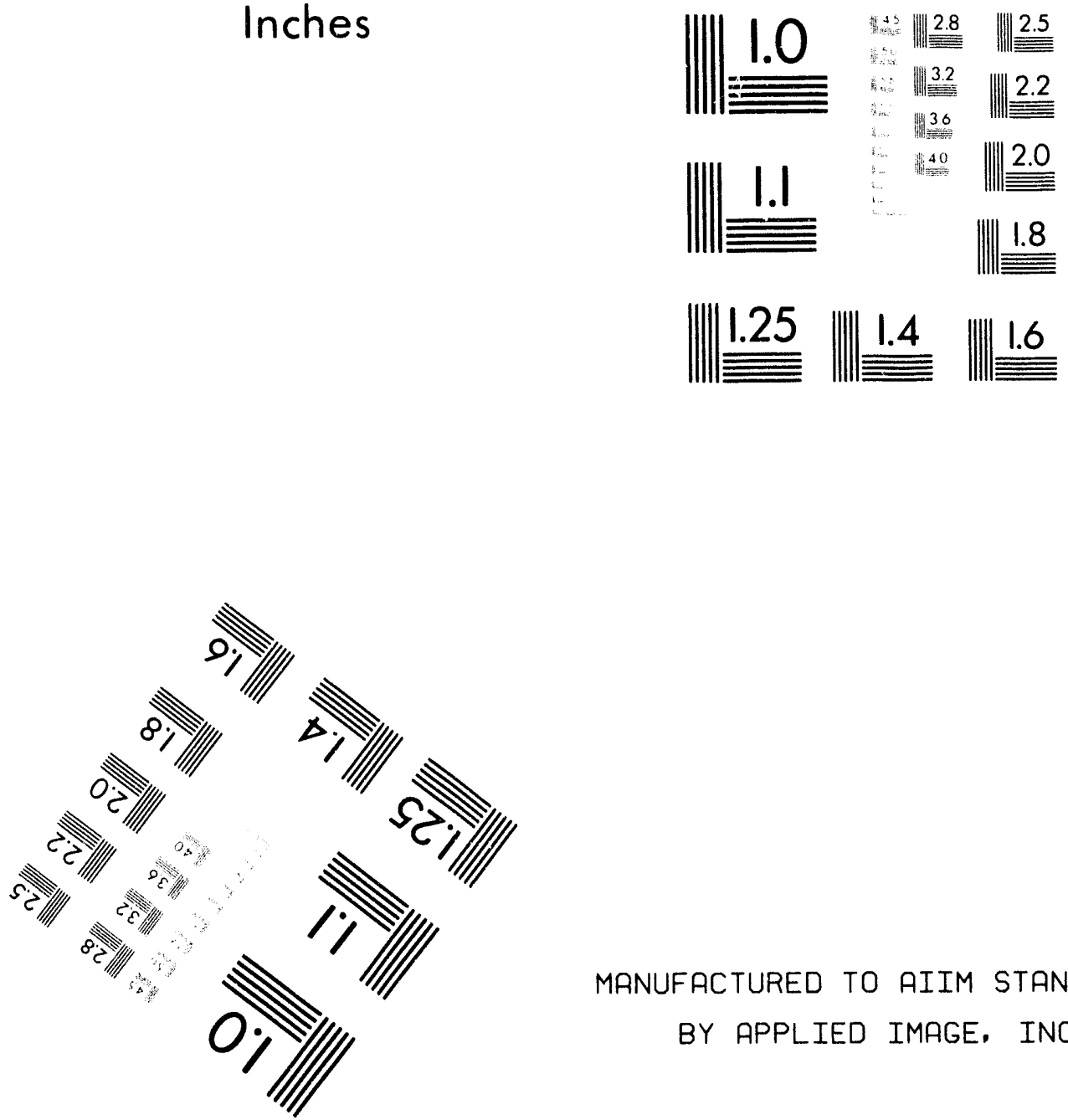

MANUFACTURED TO AIIM STANDARDS

BY APPLIED IMAGE. INC.

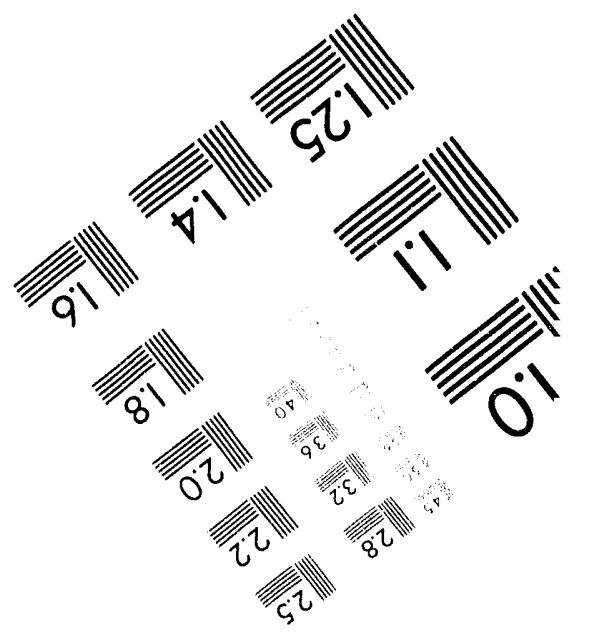



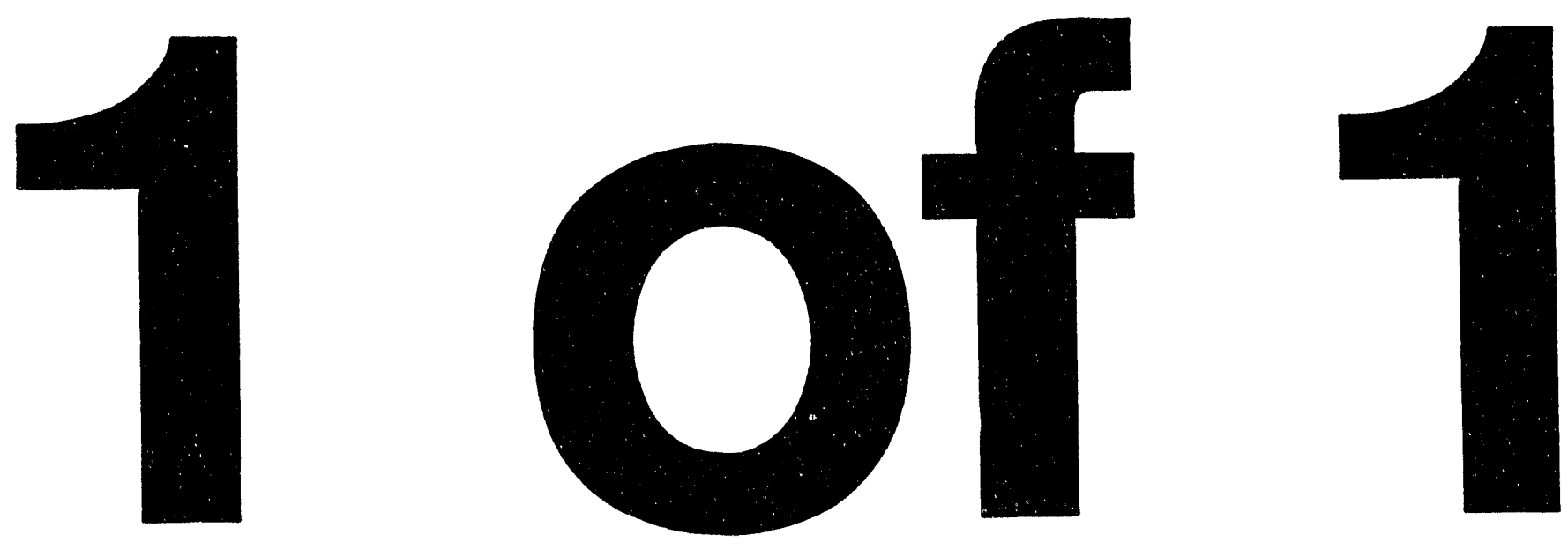


\begin{tabular}{|c|c|c|}
\hline $\begin{array}{l}\text { 2. ritle } \\
\text { Laboratory Test Plan In-Well Vapor Stripping } \\
\text { System }\end{array}$ & $\begin{array}{l}\text { 3. Number } \\
\text { WHC-SD-EN-TP-043 }\end{array}$ & $\begin{array}{c}\text { 4. Rev No. } \\
0\end{array}$ \\
\hline $\begin{array}{l}\text { 5. Key Hords } \\
\text { remediation technology, remediation design }\end{array}$ & \multicolumn{2}{|l|}{$\begin{array}{l}\text { 6. Author } \\
\text { Neme: K. J. Koegle } \\
\text { Organization/Charge code } \\
8 \mathrm{~B} 300 / \mathrm{HBACA}\end{array}$} \\
\hline \multicolumn{3}{|c|}{$\begin{array}{l}\text { 7. Abstract } \\
\text { WHC, 1994, Laboratory Test Plan In-Well Vapor Strippping System, WHC-SD-EN-TP-043, } \\
\text { Rev. 0, prepared by T. J. Gilmore (PNL) and K. J. Koegler (WHC) for Westinghouse } \\
\text { Hanford Company, Richiand, Washington. }\end{array}$} \\
\hline 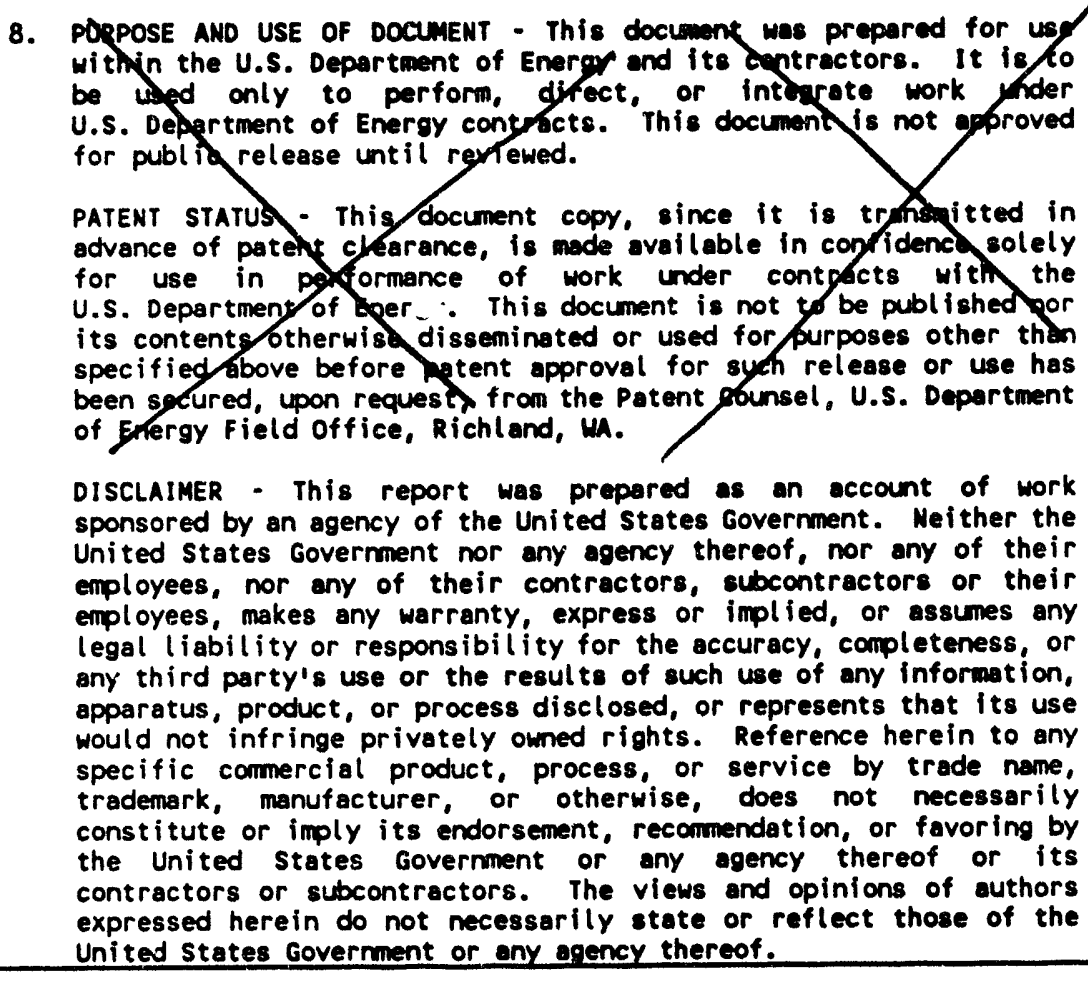 & $\begin{array}{l}\text { OFFICIALF } \\
\text { BYWH } \\
\text { DATE JUN } \\
\text { Ltation }\end{array}$ & \\
\hline 9. Impact Level $Q S$ & & \\
\hline
\end{tabular}




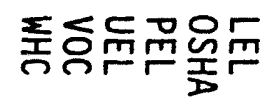

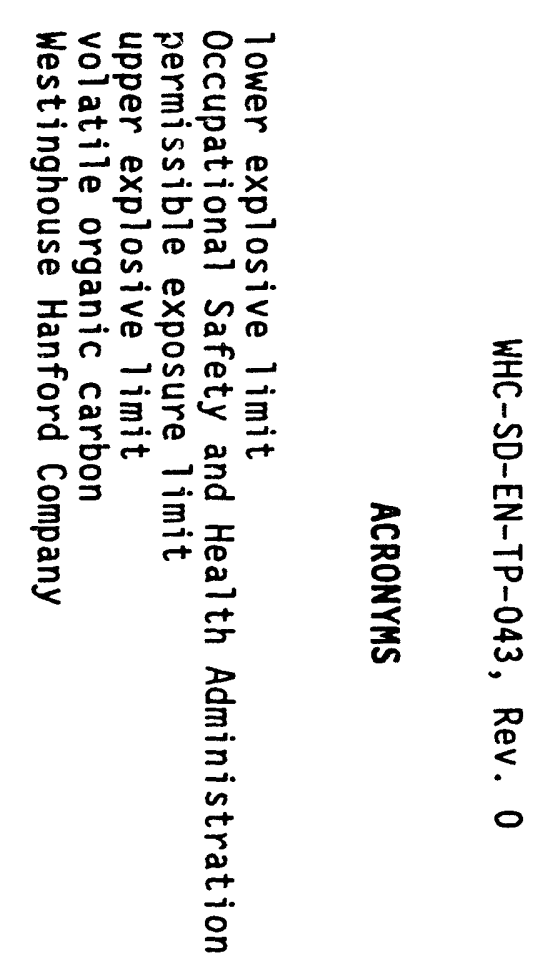




\section{Metric Conversion Chart}

The following conversion chart is provided to the reader as a tool to aid in conversion.

\begin{tabular}{|c|c|c|c|c|c|}
\hline \multicolumn{3}{|c|}{ Into Metric Units } & \multicolumn{3}{|c|}{ Out of Metric Units } \\
\hline If You Know & Multiply By & Io Get & If You Know & Multiply By & To Get \\
\hline \multicolumn{3}{|l|}{ Length } & Length & & \\
\hline inches & 25.4 & millimeters & millimeters & 0.039 & inches \\
\hline inches & 2.54 & centimeters & cent imeters & 0.394 & inches \\
\hline feet & 0.305 & meters & meters & 3.281 & feet \\
\hline yards & $0.9^{a}$ & meters & meters & 1.094 & yards \\
\hline miles & 1.609 & kilometers & kilometers & 0.621 & miles \\
\hline \multicolumn{3}{|l|}{ Area } & Area & & \\
\hline sq. inches & 6.452 & sq. cent imeters & sq. cent imeters & 0.155 & sq. inches \\
\hline sq. feet & 0.093 & sq. meters & sq. meters & 10.76 & sq. feet \\
\hline sq. yards & .0836 & sq. meters & sq. meters & 1.196 & sq. yards \\
\hline sq. miles & 2.6 & sq. kilometers & sq. kilometers & 0.4 & sq. miles \\
\hline acres & 0.405 & hectares & hectares & 2.47 & acres \\
\hline \multicolumn{3}{|c|}{ Mass (weight) } & Mass (weight & & \\
\hline ounces & 28.35 & grams & grams & 0.035 & ounces \\
\hline pounds & 0.454 & kilograms & kilograms & 2.205 & pounds \\
\hline short ton & 0.907 & metric ton & metric ton & 1.102 & short ton \\
\hline \multicolumn{3}{|l|}{ Volume } & Volume & & \\
\hline teaspoons & 5 & milliliters & milliliters & 0.033 & fluid ounces \\
\hline tablespoons & 15 & milliliters & liters & 2.1 & pints \\
\hline fluid ounces & 30 & milliliters & liters & 9.057 & quarts \\
\hline cups & 0.24 & liters & liters & 0.264 & gallons \\
\hline pints & 0.47 & liters & cubic meters & 35.315 & cubic feet \\
\hline quarts & 0.95 & liters & cubic meters & 1.308 & cubic yards \\
\hline gallons & 3.8 & liters & & & \\
\hline cubic feet & 0.028 & cubic meters & & & \\
\hline cubic yards & 0.765 & cubic meters & & & \\
\hline \multicolumn{3}{|c|}{ Temperature } & Temperature & & \\
\hline Fahrenheit & $\begin{array}{l}\text { subtract } 32 \text {, } \\
\text { then } \\
\text { multiply by } \\
5 / 9\end{array}$ & Celsius & Celsius & $\begin{array}{l}\text { mult tiply by } \\
9 / 5 \text {, then } \\
\text { add } 32\end{array}$ & Fohrenheit \\
\hline
\end{tabular}


CONTENTS

1.0 INTRODUCTION . . . . . . . . . . . . . . . . . . . . . . 1

2.0 TEST OBJECTIVES . . . . . . . . . . . . . . . . . . . 1

3.0 DESCRIPTION OF TEST ACTIVITIES • • •

3.1 SYSTEM CHECKOUT, INSTRUMENT INSTALLATION, AND CALIBRATION . . 2

3.1.1 Test Item . . . . . . . . . . . . . . . . 2

3.1.2 Test Environment . . . . . . . . . . . . . . 4

3.1.3 Equipment and Facilities .............. 4

3.1 .4 Data . . . . . . . . . . . . . . . . 4

3.1.5 Criteria/Constraints . . . . . . . . . . . . 4

3.2 PACKER TEST . . . . . . . . . . . . . . . . 5

3.2.1 Test Item ...... . . . . . . . . . . 5

3.2.2 Test Environment . . . . . . . . . . . . . . 5

3.2.3 Equipment and Facilities ............. 5

3.2 .4 Data . . . . . . . . . . . . . . . . 5

3.2.5 Criteria/Constraints . . . . . . . . . . . 5

3.3 DIFFUSER PERFORMANCE VERIFICATION . . . . . . . . . . . . 5

3.3.1 Test Item . . . . . . . . . . . . . . . 6

3.3.2 Test Environment . . . . . . . . . . . . . . 6

3.3.3 Equipment and Facilities . . . . . . . . . . . 6

3.3.4 Data . . . . . . . . . . . . . . . . 6

3.3.5 Criteria/Constraints ............... 6

3.4 VARYING LIFT AND HEAD TESTS . . . . . . . . . . . . . . 6

3.4.1 Test Item .................. . . 7

3.4.2 Test Environment ............... . 7

3.4.3 Equipment and Facilities . . . . . . . . . 7

3.4 .4 Data . . . . . . . . . . . . . . . . . 7

3.4.5 Criteria/Constraints . . . . . . . . . . . 7

3.5 TESTS UNDER SIMULATED AQUIFER CONDITIONS . . . . . . . . . 7

3.5.1 Test.Item . . . . . . . . . . . . . . . 8

3.5.2 Test Environment . . . . . . . . . . . . . . . 8

3.5.3 Equipment and Facilities ............. . 8

3.5.4 Data . . . . . . . . . . . . . . . . . . 8

3.5.5 Criteria/Constraints . . . . . . . . . . . 8

3.6 STRIPPING EFFICIENCY TESTS . . . . . . . . . . . . . . . . 9

3.6.1 Test Item . . . . . . . . . . . . . . . . 9

3.6.2 Test Environment ............... 9

3.6.3 Equipment and Facilities ............. 9

3.6.4 Data. . . . . . . . . . . . . . . 9

3.6.5 Criteria/Constraints ............ 10

4.0 EXPECTED RESULTS . • . . . . . . . . . . . . . . . 10

4.1 SYSTEM CHECKOUT, INSTRUMENT INSTALLATION, AND CALIBRATION . . 10

4.2 PACKER TEST . . . . . . . . . . . . . . . . 10

4.3 DIFFUSER PERFORMANCE VERIFICATION . . . . . . . . . . . . 11

4.4 VARYING LIFT AND HEAD TEST . . . . . . . . . . . . . . . . . . 11

4.5 TESTS UNDER SIMULATED AQUIFER CONDITIONS . . . . . . . . . . . 11

4.6 STRIPPING EFFICIENCY TEST ....................... 11 
CONTENTS (cont)

5.0 TEST PROCEDURE . . . . . . . . . . . . . . . . . 11

5.1 SYSTEM CHECKOUT, INSTRUMENT INSTALLATION, AND CALIBRATION . . II

5.1 .1 Initial Conditions ............. 11

5.1.2 Verify Instrument Calibrations .......... 12

5.1.3 Establish Initial Flows ............ 12

5.2 DIFFUSER LIFT VERIFICATION . . . . . . . . . . . . . . 13

5.2.1 Initial Conditions ............. 13

5.2.2 Establish Initial Flows ............ 13

5.2.3 Verify Diffuser Performance .......... 13

5.2 .4 Change Diffuser Assembly ............ 13

5.3 VARYING LIFT AND HEAD TESTS . . . . . . . . . . . . 14

5.3.1 Initial Conditions . . . . . . . . . . . . 14

5.3.2 Establish Initial Flows ............ 14

5.3.3 Verify Diffuser Performance at Nominal Operating Conditions .............. 14

5.3.4 Observe Performance at Decreased Head/Increased Lift. 15

5.3.5 Change Diffuser Assembly . . . . . . . . . 15

5.4 TESTS UNDER SIMULATED AQUIFER CONDITIONS . . . . . . 16

5.4 .1 Initial Conditions .............. 16

5.4.2 Establish Initial Flows . . . . . . . . 16

5.4.3 Adjust Resistance to Flow . . . . . . . . . . 16

5.4.4 Diffuser Lift Verification. . . . . . . . . . . 16

5.4.5 Varying Lift and Head Tests ......... 16

5.5 AIR STRIPPING EFFECTIVENESS TEST . . . . . . . . . . 16

5.5.1 Initial Conditions ........... 17

5.5.2 Initiate Once-Through Liquid Flow: . . . . . . 17

5.5.3 Perform Stripping Efficiency Test . . . . . . . . 17

6.0 SAFETY . . . . . . . . . . . . . . . . . . . 18

6.1 ENTRY INTO THE 306E LABORATORY PIT . . . . . . . . . . . 19

6.2 PROPANE HAZARDS .................. . . 19

6.2 .1 Propane Properties . . . . . . . . . . . . 19

6.2.2 Safety Features and Administrative Controls .... 19

7.0 qualitY ASSURANCE . . . . . . . . . . . . 20

7.1 WITNESSING OF TESTS .................. 20

7.2 INSTRUMENT CALIBRATIONS ................ 20

7.3 LICENSING REQUIREMENTS . . . . . . . . . . . . . 21

8.0 ORGANIZATION AND FUNCTION RESPONSIBILITIES . . . . . . . . . 21

8.1 306E LABORATORY ORGANIZATION ................... 21

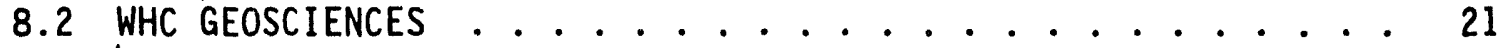

9.0 SCHEDULE . . . . . . . . . . . . . . . . . . 21

9.1 DESIGN, PROCURE AND FABRICATE STANFORD LABORATORY TEST

SYSTEM . . . . . . . . . . . . . 21

9.2 PERFORM LABORATORY TESTS ................ 21

9.3 ANALYZE TEST DATA AND PREPARE REPORT . . . . . . . . 22

10.0 REPORTS ........................ 22 
WHC-SD-EN-TP-043, Rev. 0

CONTENTS (cont)

11.0 REFERENCE .............................. 22

ATTACHMENT: DATA SHEETS .................. 23

FIGURE:

1. In-Well Vapor Stripping Test Apparatus ............ 3 


\subsection{INTRODUCTION}

This test plan describes the activities that will be conducted as a part of the laboratory testing of a full-scale mockup of the Stanford in-well vapor stripping system. These tests will be conducted to delineate design parameters for the in-well vapor stripping unit and to identify and quantify variables that are sensitive to the dynamic hydraulic effects induced by operation of the system. No radioactive materials are involved in this test.

In-well vapor stripping has been used successfully as an alternative to conventional pump-and-treat technology for remediation of volatile organic compound (VOC) contaminated groundwater in Europe and more recently in the United States. In-well vapor stripping permits in situ remediation of VOC-contaminated groundwater by combining an in-well vapor stripping system with a treatment well screened over two distinct intervals. The multiplescreened treatment well is used to extract and discharge groundwater simultaneously, resulting in the establishment of a vertical circulation groundwater flow cell in the aquifer. Groundwater extracted from the aquifer via the lower screened interval is treated for VOCs by in-well vapor stripping within the treatment well. This stripping causes aqueous phase VOCs to partition preferentially into a vapor phase. Treated groundwater is discharged back to the aquifer via the upper screened interval of the treatment well, while the vapor phase VOCS are simultaneously removed from the well bore and contained at the surface with a vacuum extraction system. Groundwater entrained into the vertical circulation flow cell becomes sequentially cleaned of VOC contamination in an efficient. manner without the need for surface treatment and handling of contaminated groundwater. An added benefit of in-well vapor stripping is the ability to perform vadose zone vapor extraction concurrently with groundwater remediation. This uses the vacuum extraction capabilities of the in-well vapor stripping configured with the upper screened interval.placed into the vadose zone above the water table.

An in-well vapor stripping system has been developed by faculty at Stanford University (Gvirtzman and Gorelick 1992) to treat VOC-contaminated groundwater. This system has been referred to as the Stanford in-well vapor stripping system. This system is currently in the conceptual design phase and has not been field tested. Large-scale laboratory testing of a prototype followed by field installation is planned.

\subsection{TEST OBJECTIVES}

The laboratory tests of the Stanford prototype and we 11 mockup are designed to accomplish the following objectives.

- Calibrate the integral flow measurement weir and its associated transducer against a measured flow rate and develop relationships between the water flow measured by the weir system, air flow rate, and supply air pressure.

- Test the packer design for field installation. 
- Test the effects of varying lift, head (submergence), and air flow rate on system performance.

- Test the effects of various diffusers on system performance.

- Gather data on the air holdup and actual air velocity within the vapor stripping well as a function of air flow rate and submergence.

- Evaluate the stripping efficiency of the in-well vapor stripping.

\subsection{DESCRIPTION OF TEST ACTIVITIES}

The test objectives outlined in Chapter 2.0 will be accomplished through a series of testing activities. These activities include the following:

- System checkout, instrument installation, and calibration

- Packer test

- Diffuser performance verification

- Varying lift and head test

- Tests under simulated aquifer conditions

- Stripping efficiency test.

These test activities are more fully described in Sections 3.1 through 3.6 .

\subsection{SYSTEM CHECKOUT, INSTRUMENT INSTALLATION, AND CALIBRATION}

During this phase of testing, the system instrumentation will be calibrated and the system equipment will be checked for proper operation. Once the system is functioning properly, the weir and its associated pressure transducer will be calibrated against the water flow rate, which is measured by a calibrated inline flowmeter. A relationship between the water flow rate measured by the weir, the supply air flow rate, and the supply air pressure will be determined. Selected portions of the test activities will be videotaped using a portable camcorder and/or photographed using still cameras positioned at various heights along the well mockup.

\subsubsection{Test Item}

This activity will test the Stanford prototype weir device, sparger, and air eductor assemblies fabricated at the Hanford Site $306 \mathrm{E}$ Laboratory facility (Figure 1). 
Figure 1. In-Well Vapor Stripping Test Apparatus.

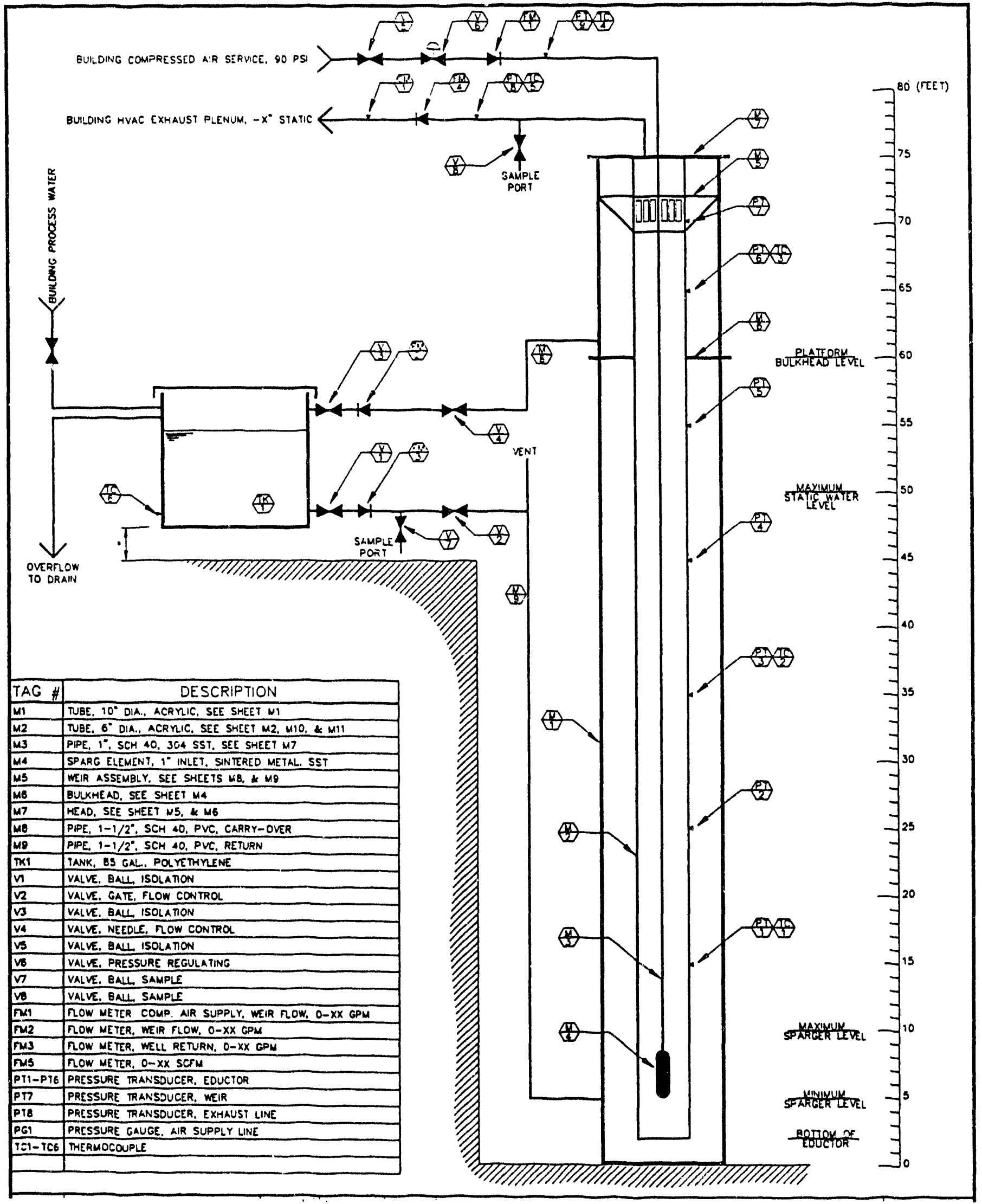




\subsubsection{Test Environment}

This activity will occur in the $306 \mathrm{E}$ Laboratory facility. in the 300 Area. The full-scale Stanford prototype and well mockup will be installed in the test pit of the $306 \mathrm{E}$ Laboratory.

\subsubsection{Equipment and Facilities}

This testing activity will require the following equipment:

- The circulation well mockup assembly installed in the $306 \mathrm{E}$ Laboratory test pit (see Figure 1)

- An air compressor or building compressed air supply capable of providing between 1 and $25 \mathrm{ft}^{3} / \mathrm{min}$ of air flow at a pressure of up to $95 \mathrm{ft}$ of water (approximately $40 \mathrm{lb} / \mathrm{in}^{2}$ )

- A building ventilation/vessel vent system capable of removing up to $25 \mathrm{ft}^{3} / \mathrm{min}$ of air flow

- Supporting instrumentation, including air flow, temperature, and pressure meters on the air supply and discharge; a liquid

flowmeter factory calibrated to $\pm 1 \%$ accuracy over the range of 10 to $100 \mathrm{gal} / \mathrm{min}$; pressure transducers; combustible gas meters; and a datalogger

- 5-gal U.S. Department of Transportation approved container of liquified petroleum gas (propane)

- Approximately 200 to 250 gal of sanitary water.

\subsubsection{Data}

Data collected during this activity will include the following:

- Water flow rate measured by the liquid flowmeter as a function of system air flow rate and supply air pressure

- Pressure measured by the transducer in the weir as a function of the flow rate measured by the liquid flowmeter

- Pressure and temperature (both wet and dry bulb) of the air stream entering and exiting the test well and of the air/water mixture at various points within the well as measured by the installed monitoring equipment.

\subsubsection{Criteria/Constraints}

No special criteria or constraints are applicable to this test activity. 


\subsection{PACKER TEST}

During this testing activity, the proposed well packer design for the Stanford system will be leak tested. After leak testing, several inches of silty sand will be placed on the packer to simulate the buildup of sediments during operation, and the effect on the packer seal and withdrawal of the packer assembly will be determined.

\subsubsection{Test Item}

The item to be tested during this activity is the prototype integral inwell packer assembly to be manufactured as a part of the field Stanford system.

\subsubsection{Test Environment}

This activity will occur in the 306E Laboratory using a test bed consisting of an 11- to.12-ft-long by 6-in.-diameter stainiess steel pipe inside an 11- to 12-ft-long by 10-in.-diameter stainless steel pipe. The packer will be placed between the 6-in. and 10-in. pipes.

\subsubsection{Equipment and Facilities}

This activity will require the test bed described above, a small amount of sand (less than $25 \mathrm{lb}$ ), and approximately $35 \mathrm{gal}$ of sanitary water.

\subsubsection{Data}

During this test, the test bed and packer will be visually observed to determine if leakage is occurring. The ease of withdrawing the packer with a sediment buildup will be subjectively determined.

\subsubsection{Criteria/Constraints}

No special criteria or constraints are applicable to this test activity.

\subsection{DIFFUSER PERFORMANCE VERIFICATION}

During this test activity, each diffuser wiil be tested to determine the range of liquid flow rates that can be achieved at a constant lift of 25 to $27 \mathrm{ft}$. The bubble size and production rate of each diffuser will be observed and qualitatively evaluated. Selected portions of the test activities will be videotaped using a portable camcorder and/or photographed using still cameras positioned at various heights along the well mockup. 


\subsubsection{Test Item}

This activity will test the Stanford prototype eductor pipe and diffuser assembly fabricated at the 306E Laboratory facility. The eductor pipe will be fitted with a variety of sintered metal diffuser devices of varying porosities.

\subsubsection{Test Environment}

This activity will occur in the 306E Laboratory facility in the 300 Area. The full-scale Stanford prototype and well mockup will be installed in the test pit of the $306 \mathrm{E}$ Laboratory.

\section{3.j Equipment and Facilities}

Equipment and facilities required for this activity are the same as those described in Section 3.1.3.

\subsubsection{Data.}

The following data will be collected during this activity:

- Supply air pressure, air temperature, and water temperature as a function of air flow rate

- Water flow rate (measured both by the weir/transducer and the water flowmeter) as a function of air flow rate and water head at a constant lift

- Bubble size-and production rate based upon qualitative observations of the well mockup and scaled photographs

- Pressure and temperature (both wet and dry bulb) of the air stream entering and exiting the test well and of the air/water mixture at various points within the well as measured by the installed monitoring equipment.

\subsubsection{Criteria/Constraints}

No special criteria or constraints are applicable to this test activity.

\subsection{VARYING LIFT AND HEAD TESTS}

Of the diffuser assemblies that pass the minimum performance tests described in Section 3.3, the two assemblies that are anticipated to exhibit the highest mass transfer rates (based upon bubble size and production rate evaluations) will be tested further. These tests will evaluate system operation, including well drawdown/mounding, at various combinations of 1 ift and head (submergence). Selected portions of the test activities will be 
videotaped using a portable camcorder and/or photographed using still cameras positioned at various heights along the well mockup.

\subsubsection{Test Item}

The test item for this activity is the Stanford assembly described in Section 3.1.1, fitted with the diffusers described in Section 3.4.

\subsubsection{Test Environment}

This activity will occur in the 306E Laboratory facility in the 300 Area. The full-scale Stanford prototype and well mockup will be installed in the test pit of the 306E Laboratory.

\subsubsection{Equipment and Facilities}

Equipment and facilities required for this activity are the same as those described in Section 3.1.3.

\subsubsection{Data}

Data to be collected during this activity will include the following:

- Supply air pressure, air temperature, and water temperature as a function of air flow rate

- Water flow rate (measured both by the weir/transducer and the water flowmeter) as a function of air flow rate and water head at a constant lift

- Bubble size and production rate, based upon qualitative observations of the well mockup and scaled photographs

- Pressure and temperature (both wet and dry bulb) of the air stream entering and exiting the test well and of the air/water mixture at various points within the well as measured by the installed monitoring equipment.

\subsubsection{Criteria/Constraints}

- No special criteria or constraints are applicable to this test activity.

\subsection{TESTS UNDER SIMULATED AQUIFER CONDITIONS}

These tests will use valving to introduce flow resistance in the piping between the test well mockup and the surge tank. The flow resistances will cause water level drawdown/mounding in the test well, simulating the 
conditions that will occur during actual field operation of the Stanford system.

\subsubsection{Test Item}

The test item for this activity is the Stanford assembly described in Section 3.1.1, fitted with the diffusers described in Section 3.4.

\subsubsection{Test Environment}

This activity will occur in the 306E Laboratory facility in the 300 Area. The full-scale Stanford prototype and well mockup will be installed in the test pit of the $306 \mathrm{E}$ Laboratory.

\subsubsection{Equipment and Facilities}

Equipment and facilities required for this activity are the same as those described in Section 3.1.3.

\subsubsection{Data}

The following data will be collected during this activity:

- Supply air pressure, air temperature, and water temperature as a function of air flow rate

- Water flow rate (measured both by the weir/transducer and the water flowmeter) as a function of air flow rate and water head at a constant lift

- Bubble size and production rate, based upon qualitative observations of the well mockup and scaled photographs

- Pressure and temperature (both wet and dry bulb) of the air stream entering and exiting the test well and $r i$ the air/water mixture at various points within the well as measured by the installed monitoring equipment.

- Static and operating water levels in the upper and lower sections of the outer 10-in. well.

\subsubsection{Criteria/Constraints}

No special criteria or constraints are applicable to this test activity. 


\subsection{STRIPPING EFFICIENCY TESTS}

Propane has been initially selected for use in the stripping efficiency test. Alternate compounds may also be considered. The air stripping efficiency of the vapor stripping well will be evaluated by mixing propane gas into the recirculated liquid and comparing the propane concentration in the liquid entering the stripping well to he propane concentrations in the liquid at the top of the well and in the gas stream exiting the well. Propane gas has been selected bec use it has a Henry's Law constart similar to that of carbon tetrachloride but does not present the health and environmental concerns of carbon tetrachloride.

\subsubsection{Test Item}

The test item for this activity is the Stanford assembly described in Section 3.1.1, fitted with the diffusers described in Section 3.4.

\subsubsection{Test Environment}

This activity will occur in the 306E Laboratory facility in the 300 Area. The full-scale Stanford prototype and well mockup will be installed in the test pit of the 306E Laboratory.

\subsubsection{Equipment and Facilities}

Equipment and facilities required for chis activity are the same as those described in Section 3.1.3. Additionally, less than 5 gal of propane gas will be used during the course of the test.

\subsubsection{Data}

Data to be collected during this activity will include the following:

- Supply air pressure, air temperature, and water temperature as a function of air flow rate

- Water flow rate (measured both by the weir/transducer and the water flowmeter) as a function of air flow rate and water head at a constant lift

- Bubble size and production rate, based upon qualitative observations of the well mockup and scaled photographs

- Pressure and temperature (both wet and dry bulb) of the air stream entering and exiting the test well and of the air/water mixture at various points within the well as measured by the installed monitoring equipment

- Propane concentrations in the water entering and exiting the test well and in the gas stream entering and exiting the test well. 


\subsubsection{Criteria/Constraints}

Special criteria and constraints applicable to this test activity are discussed under Safety in Chapter 6.0.

\subsection{EXPECTED RESULTS}

\subsection{SYSTEM CHECKOUT, INSTRUMENT INSTALLATION, AND CALIBRATION}

Relationships between pressures measured in the Stanford flow weir and actual liquid flow rates will be determined. To be successful, the weir and transducer must allow the actual flow rate to be determined independent of the supply air flow rate used.

During the calibration of the weir assembly, the overall ability of the system to provide $20 \mathrm{ft}$ of lift at a head of $40 \mathrm{ft}$ will be checked to ensure that the system design can reasonably accomplish the objectives stated for other test activities.

Fluid pressure and temperature at various heights within the iest well will be continuously monitored and logged. These data will be used to estimate the gas holdup of the vapor stripping well under various operating conditions. Pressure transducers should be able to detect at least a 0.5 psi change. Thermocouples should be able to detect at least a $0.5{ }^{\circ} \mathrm{C}$ change, and flowmeters should be able to detect at least a $0.5 \mathrm{gal} / \mathrm{min}$ change.

\subsection{PACKER TEST}

To be considered successful, the prototype packer assembly should allow no visible leakage of water from the region above the packer to the region below the packer both before and after the simulated sediment is added to the system under maximum expected mounding conditions. The packer should also be able to be withdrawn from the test bed freely, with no jamming, when removal is attempted after sediments are added.

\subsection{DIFFUSER PERFORMANCE VERIFICATION}

Diffusers that pass the performance verification test will be able to sustain $20 \mathrm{ft}$ of $1 \mathrm{ift}$ and $40 \mathrm{ft}$ of head (submergence) at operating flow rates of between 10 and $40 \mathrm{gal} / \mathrm{min}$ with no evidence of annular air flow. Diffusers selected for further evaluation will achieve the widest range of liquid flow rates and will produce the highest volumes of small air bubbles without producing annular air flow. 


\subsection{VARYING LIFT AND HEAD TEST}

This test activity will be considered successful if at least one diffuser assembly is able to sustain a minimum of $10 \mathrm{gal} / \mathrm{min}$ of water flow over a variety of lift and head combinations without producing annular fluw. Transient drawdoin/mounding combinations will also be observed.

\subsection{TESTS UNDER SIMULATED AQUIFER CONDITIONS}

These tests will evaluate the operable range of flow rates, lifts, and submergences of a test well with design characteristics similar to the test well mockup. Conditions that would adversely affect the performance of the well in the field (e.g., excessive drawdown or water mounding that would interfere with. the flow measurement weir) will be identified.

\subsection{STRIPPING EFFICIENCY TEST}

The propane in the gas leaving the vapor stripping well is anticipated to be nearly at equilibrium with the propane in the liquid within the well for the bubble and small slug flow regimes. The purpose of the stripping test is to confirm and refine the correlations and equations used to predict the vapor phase VOC concentrations achieved by the in-well vapor stripping.

\subsection{TEST PROCEDURE}

The following sections provide step-by-step instructions for performing the test activities described in Chapter 3.0 .

\subsection{SYSTEM CHECKOUT, INSTRUMENT INSTALLATION, AND CALIBRATION}

\subsubsection{Initial Conditions}

The following conditions must exist before test activities are initiated.

The Stanford prototype system will have been installed in the well mockup.

- A diffuser will have been installed on the Stanford eductor.

- The main well will have been filled with water to the static water level. 
- The water level in the surge tank will be in equilibrium with the water level in the main well.

- All system valves will be closed.

\subsubsection{Verify Instrument Calibrations}

5.1.2.1 Supply Air Instrumentation. Ensure that supply air flowmeter, temperature gauge, and pressure gauge calibrations have been performed in accordance with manufacturer's instructions and/or WHC procedures and that calibrations are current. Calibrate instruments if required. Record calibration date on data sheet.

5.1.2.2 Liquid Flowmeter. Verify that liquid flowmeter has been calibrated by manufacturer before receipt.

5.1.2.3 Pressure Transducers. Ensure that the pressure transducers have been cal ibrated in accordance with manufacturer's instructions and/or WHC procedures and that calibrations are current. Calibrate if required. Record calibration date on data sheet.

5.1.2.4 Datalogger. Ensure that the datalogger used to record signals from the pressure transducers and thermocouples has been calibrated in accordance with manufacturer's instructions and/or WHC procedures and that calihrations are current. Calibrate if required. Record calibration date on data sheet.

\subsubsection{Establish Initial Flows}

5.1.3.1 Align System Valving Properly. Open the return valves fully between test well to reservoir tank and between the reservoir tank and the test well. Ensure that sample valves are in the flow-through (and not sampling) positions. Ensure that the sewer discharge valve is in the recirculation position.

5.1.3.2 Begin Air Flow: Open air supply valve and adjust to allow approximately $0.25 \mathrm{stdft}^{3} / \mathrm{min}$ air flow.

\subsubsection{Calibrate Pressure Weir}

5.1.4.1 Establish Initial Flow Condition. Allow liquid flowmeter readings and weir pressure transducers to attain steady state at $0.25 \mathrm{stdft}^{3} / \mathrm{min}$ air flow. Record following system variables when steady state is attained:

\footnotetext{
- Time steady state conditions were observed

- Supply and exhaust air flow rate

- Supply and exhaust air wet and dry bulb temperatures

- Liquid flow rate, as measured by reservoir tank flowmeter

- Fluid pressures and temperatures along test well height

- Observed flow regime (bubble, slug, churn, annular)

- Weir transducer pressure reading.
} 
5.1.4.2 Calibrate Overflow Range. Repeat Step 5.1.4.1, increasing air flow rate in $0.25 \mathrm{stdft}^{3} / \mathrm{min}$ increments unt il annular flow is observed or maximum supply air flow is attained. Record the system variables listed in Step 5.1.4.1 for each air flow setting.

\subsection{DIFFUSER LIFT VERIFICATION}

\subsubsection{Initial Conditions}

Repeat system verification steps listed in Sections 5.1.1 and 5.1.2.

\subsubsection{Establish Initial Flows}

5.2.2.1 Align System Valving Properly. Open the return valves fully between test well to reservoir tank and between the reservoir tank and the test well. Ensure that sample valves are in the flow-through (and not sampling) positions. Ensure that the sewer discharge valve is in the recirculation position.

5.2.2.2 Begin Air Flow. Open air supply valve and adjust to allow approximately $0.25 \mathrm{stdft}^{3} / \mathrm{min}$ air flow.

\subsubsection{Verify Diffuser Performance}

5.2.3.1 Verify Performance at Minimum Flow. Adjust air flow to establish $10 \mathrm{gal} / \mathrm{min}_{3}$ liquid flow as measured by liquid flowmeter (approximately $0.25 \mathrm{stdft}^{3} / \mathrm{min}$ air flow). Allow system to stabilize, and record following variables:

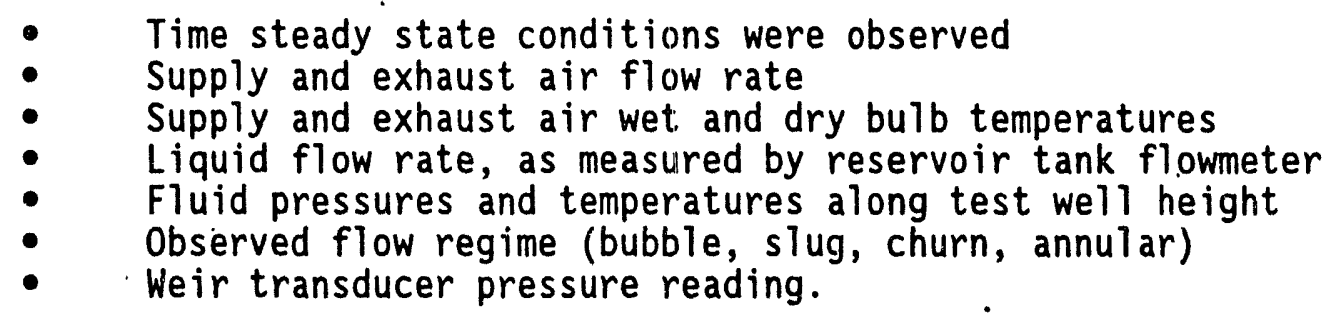

5.2.3.2 Verify Performance at Increasing Flow Rates. Increase air flow in $0.25 \mathrm{stdft}^{3} / \mathrm{min}$ increments until maximum air flow rate achievable by the supply system is reached or annular flow is observed. At each air flow rate, record the system variables listed in Section 5.3.3.1.

\subsubsection{Change Diffuser Assembly} be tested.

NOTE: Repeat the steps in Section 5.3.4 for each diffuser assembly to

5.2.4.1 Withdraw Stanford System. Remove Stanford system from well mockup.

5.2.4.2 Instal1 New Diffuser Assembly. Disassemble Stanford system as 
required to expose sparger and diffuser. Remove current diffuser from Stanford system. Install new diffuser assembly.

5.2.4.3 Reinsert Stanford System and Test New Diffuser Assembly. Reinsert Stanford system into well mockup. Perform Steps in Sections 5.3.1 through 5.3.3.2.

\subsection{VARYING LIFT AND HEAD TESTS}

\subsubsection{Initial Conditions}

Repeat system verification steps listed in Sections 5.1.1 and 5.1.2.

\subsubsection{Establish Initial Flows}

5.3.2.1 Align System Valving Properly. Open the return valves fully between test well to reservoir tank and between the reservoir tank and the test well. Ensure that sample valves are in the flow-through (and not sampling) positions. Ensure that the sewer discharge valve is in the recirculation position.

5.3.2.2 Begin Air Flow. Open air supply valve and adjust to allow approximately $0.25 \mathrm{stdft}^{3} / \mathrm{min}^{2}$ air flow.

\subsubsection{Verify Diffuser Performance at Nominal Operating Conditions}

NOTE: For Steps in Sections 5.4.3.1 and 5.4.3.2, the water level in the test well and surge tank should be at the maximum static water level.

5.3.3.1 Verify Performance at Minimum Flow. Adjust air flow to establish $10 \mathrm{gal} / \mathrm{min}$ liquid flow as measured by liquid flowmeter (approximately $0.25-\mathrm{stdft}^{3} / \mathrm{min}$ air flow). Allow system to stabilize and record following variables:

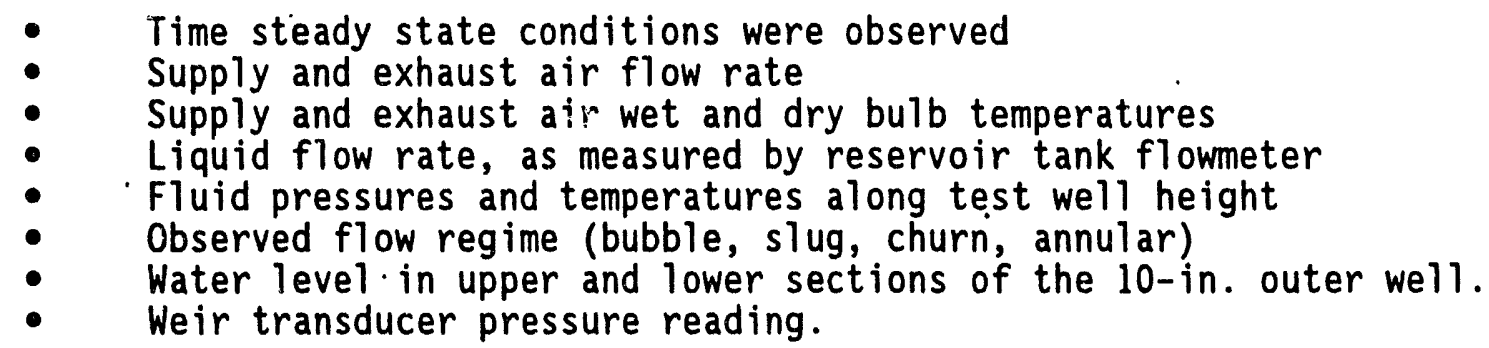

5.3.3.2 Verify Performance at Maximum Flow Rate. Increase the air flow rate to the value corresponding to the maximum flow rate achieved for that diffuser in the tests in. Section 5.3. Once steady state conditions are achieved, record the variables noted in Section 5.4.3.1. 


\subsubsection{Observe Performance at Decreased Head/Increased Lift}

NOTE: Every $1 \mathrm{ft}$ of distance along the test well equals approximately $3.5 \mathrm{gal}$ of water.

5.3.4.1 Decrease Operating Head/Increase Lift. While system is running, switch the recirculation/sewer discharge valve to the sewer discharge position. Allow 8 to $9 \mathrm{gal}$ of water to flow to the sewer. Reset valve to the recirculate position. This should reduce the static water level in the test well by between 2.25 and $2.5 \mathrm{ft}$.

5.3.4.2 Verify Performance Overflow Rate Range. Adjust air flow until $10 \mathrm{gal} / \mathrm{min}$ liquid flow rate is achieved as measured by the liquid flowmeter. Allow system to stabilize and record system variables noted in

Section 5.4.3.1. Increase air flow in 0.25 stdft $^{3} /$ min increments until maximum air flow rate achievable by the supply system is reached or annular flow is observed. At each air flow rate, record the system variables noted in Section 5.4.3.1. once steady state conditions are achieved. Shut down air flows, allow system fluid levels to equilibrate, and record actual static water level in the test well.

5.3.4.3 Observe Performance at Decreased Head/Increased Lift. Restart well flows as described in Sections 5.4.3.1 and 5.4.3.2. Further reduce head/increase lift as described in Section 5.4.4.1. Observe system performance over flow rate range as described in Section 5.4.4.2. Repeat until one of the following conditions is reached:

- $.10 \mathrm{gal} / \mathrm{min}$ water flow cannot be sustained with the maximum air flow available

- $10 \mathrm{gal} / \mathrm{min}$ water flow cannot be sustained without encountering annular flow conditions.

\subsubsection{Change Diffuser Assembly} be tested.

NOTE: Repeat the steps in Section 5.4.5 for each diffuser assembly to

5.3.5.1 Withdraw Stanford System. Remove Stanford system from well mockup.

5.3.5.2 Install New Diffuser Assembly. Disassemble Stanford system as required to expose sparger and diffuser. Remove current diffuser from Stanford system. Instail new diffuser assembly.

5.3.5.3 Reinsert Stanford System. Reinsert Stanford system into well mockup. Perform Steps in Sections 5.4.1 through 5.4.2.2. 


\subsection{TESTS UNDER SIMULATED AQUIFER CONDITIONS}

\subsubsection{Initial Conditions}

Repeat system verification steps listed in Sections 5.1.1 and 5.1.2.

\subsubsection{Establish Initial Flows}

Establish initial syscem flows as described in Section 5.1.3.

\subsubsection{Adjust Resistance to Flow}

NOTE: At a 20-gal/min flow rate and a 30-ft/day effective flow resistance (aquifer conductivity plus well losses) and a $10-\mathrm{ft}$ well screen section, a drawdown of approximately $6 \mathrm{ft}$ is anticipated to occur in an actual well installation with geometry similar to that of the test well.

This section may be repeated using different initial drawdown settings to simulate various effective flow resistances.

5.4.3.1 Increase System Flow Rate to $20 \mathrm{gal} / \mathrm{min}$. Adjust air flow rate as required to achieve a $20-\mathrm{gal} / \mathrm{min}$ recirculating flow rate. Allow system fluid levels to equilibrate.

5.4.3.2 Adjust Return Flow From Test Well. Using upper control (gate or needle) valve, reduce the return flow from the test well until the level in the upper portion of the 10-in. test well increases to approximately $6 \mathrm{ft}$ above the separation plate. Adjust the flow as required using the lower control valive to maintain 6 - ft increase in level.

5.4.3.3 Adjust Return Flow from Test Well. Using lower control (gate or needle) valve, reduce the return flow to the test well until the level in the lower portion of the 10-in. test well decreases approximately $6 \mathrm{ft}$ below the maximum static water level (to about $44 \mathrm{ft}$ ).

\subsubsection{Diffuser Lift Verification}

Repeat tests described in Section 5.3. Do not adjust control valves during tests.

\subsubsection{Varying Lift and Head Tests}

Repeat tests described in Section 5.4. Do not adjust control valves during tests.

\subsection{AIR STRIPPING EFFECTIVENESS TEST}

The following instructions will test the air stripping effectiveness of 
the Stanford system on the test well under the following conditions:

- $10 \mathrm{gal} / \mathrm{min}$ liquid flow rate

- Simulated $2.5 \mathrm{mg} / \mathrm{L}$, or $1.6 \times 10^{-6} \mathrm{~mol} / \mathrm{L}$, carbon tetrachloride concentration in groundwater

- Valving set to simulate an effective flow resistance of $30 \mathrm{ft} /$ day.

\subsubsection{Initial Conditions}

Repeat Steps in Sections 5.5.1 through 5.5.3.3. In addition, perform the following steps:

- Ensure that all propane piping and valves have been leak tested at normal operating pressure

- Ensure that combustible gas meter has been calibrated to propane

- Confirm that ventilation system, including surge tank ventilation system, is operational

- Adjust airflow to obtain a $10 \mathrm{gal} / \mathrm{min}$ liquid flow rate.

\subsubsection{Initiate Once-Through Liquid Flow.}

5.5.2.1 Open Water Supply Valve. Open water supply valve and establish a $10 \mathrm{gal} / \mathrm{min}$ flow of water to the test system.

\subsubsection{Perform Stripping Efficiency Test}

NOTE: The anticipated carbon tetrachloride concentration in groundwater at the 200 West Area in-well vapor stripping test site is approximately $2.5 \mathrm{mg} / \mathrm{L}$, ur $1.6 \times 10^{-6} \mathrm{~mol} / \mathrm{L}$. To obtain a $1.6 \times 10^{-6} \mathrm{~mol} / \mathrm{L}$ concentration of propane in the water, approximately $0.001 \mathrm{~L}$ of pure propane must be dissolved into every galion of water at standard conditions ( $1 \mathrm{~atm}$ pressure and $0{ }^{\circ} \mathrm{C}$ ). The following instructions assume that approximately $90 \%$ of the pure propane injected into a $10 \mathrm{gal} / \mathrm{min}$ water supply is dissolved; the flow settings may be adjusted to obtain differing concentrations for various water supply flow rates.

5.5.3.1 Initiate Propane Flows. Open propane supply valve and adjust valving until a $0.7 \mathrm{~L} / \mathrm{hr}$ propane flow rate is established.

NOTE: No smoking or open flames are allowed in the vicinity of the propane storage area or test well mockup. Propane flows must be shut off if any of the following conditions occur:

- Building or test well mockup system ventilation is interrupted

- Propane piping must be repaired or adjusted (fittings tightened) 
- Water flow is interrupted

- Test activities are delayed or test system is unattended.

The airspace within the surge tank will be monitored every 15 minutes while the propane is flowing. If propane concentrations in the surge tank exceed $15 \%$ of the lower explosive limit (LEL), propane flows will be shut off and not reestablished until propane concentrations in the surge tank fall to background levels. For propane, $15 \%$ of the LEL is equivalent to an air concentration of 3,200 ppm.

5.5.3.2 Record System Data. Monitor the exhaust system combustible gas meter. The combustible gas meter should be able to detect propane to at least $10 \mathrm{ppm}-\mathrm{v}$. When the combustible gas meter reading stabilizes (anticipated readings are on the order of 100 to $1,000 \mathrm{ppmv}$ ), record system data:

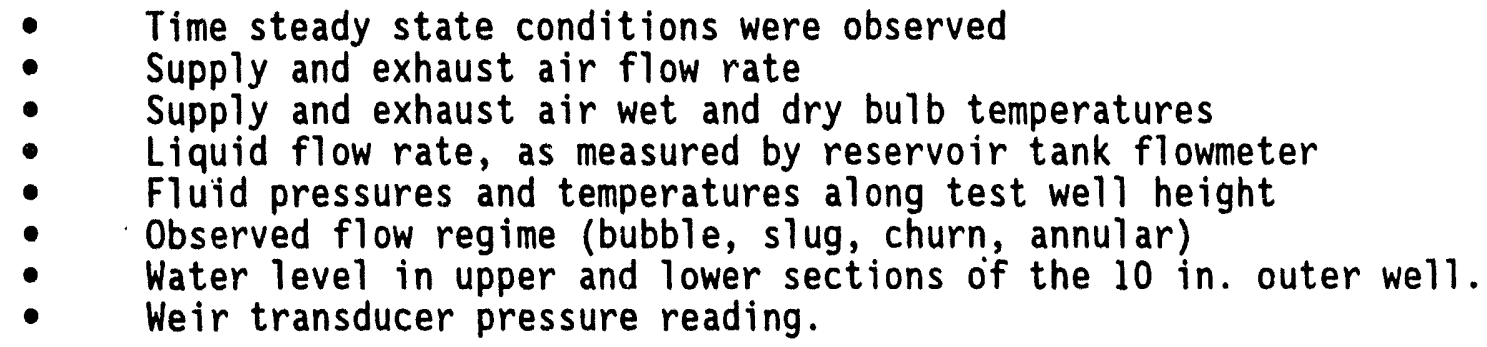

5.5.3.3 Collect Air and Water Samples. Collect air and water samples at the following locations:

- Inlet air sample valve

- Outlet air sample valve

- Water return to test well sample valve

- Water return from test well sample valve.

Air samples are to be collected in Tedlar (a registered trademark of E.I. du Pont de Nemours and Company, Wilmington, Delaware) bags. Water samples are to be collected in $40 \mathrm{~mL}$ glass vials with nonstick caps and septa. Take care to minimize agitation of the water samples, and ensure that no airspace is left in the sample vials. Submit samples for analysis for propane by gas chromatography. Analysis should be able to detect at least $20 \mathrm{ppb}$ propane in water and air.

5.5.3.4 Test Conclusion. Once all readings are obtained and samples collected, close propane supply valve. Set sewer discharge/recirculation flow valve to the recirculation position. Close water supply valve.

\subsection{SAFETY}

The key safety concerns for this test include the following:

- Entry into the $306 \mathrm{E}$ Laboratory pit

- Potential hazards caused by propane. 


\subsection{ENTRY INTO THE 306E LABORATORY PIT}

Entry into the $306 \mathrm{E}$ Laboratory pit will be required for several test activities, including installation and operation of test equipment. Entries into the 306E Laboratory pit will be performed in accordance with standard approved procedures.

\subsection{PROPANE HAZARDS}

Propane has been chosen for use in these tests as a low-toxicity, noncarcinogenic surrogate for carbon tetrachloride. Other compounds may be considered for use in these stripping tests. On a molar basis, the Henry's Law constant for propane $\left(2.2 \times 10^{-2} \mathrm{~atm}-\mathrm{mol} / \mathrm{m}^{3}\right)$ is approximately the same as that for carbon tetrachloride $\left(2.41 \times 10^{-2}\right.$ to $\left.3.0 \times 10^{-2} \mathrm{~atm}-\mathrm{mol} / \mathrm{m}^{3}\right)$; therefore, propane is an appropriate substitute for carbon tetrachloride for test purposes. Propane was selected for these tests using a process that considered the following:

- The Henry's Law constants and solubilities of potential surrogate compounds

- Environmental and health and saciety considerations, including whether or not the disposal of wastes or air emissions generated by test activities would be subject to state and federal environmental regulations)

- Availability, cost, and ease of use.

\subsubsection{Propane Properties}

Propane is a colorless, heavier-than-air gas that is flammable and can act on the central nervous system. Commercial propane typically has an odorant added to allow detection by smell and is generaliy supplied as a liquified compressed gas. Inhalation can cause dizziness or disorientation. Skin contact can cause excitation or frostbite because of the low temperatures caused by the expansion of the pressurized liquid into the gas phase. Clothing that becomes saturated with propane can be flammable. The LEL for propane is 2.1 vol\%; the upper explosive limit (UEL) is 9.5 vol\%. The Occupational Safety and Health Administration (OSHA) permissible exposure limit (PEL) for. propane is $1,000 \mathrm{ppm}\left(1,800 \mathrm{mg} / \mathrm{m}^{3}\right)$.

\subsubsection{Safety Features and Administrative Controls}

A separate safety review will be performed at the 306E Laboratory before initiating the stripping efficiency tests. Propane flow rates will be controlled such that the propane concentrations in the offgas from the test well, as measured by the inline combustible gas meter, remain less than 1,000 $\mathrm{ppm}$. This maximum concentration is approximately $5 \%$ of the LEL. Therefore, it is unlikely that the offgas from the test well poses a fire or explosion hazard. Similarly, concentrations of propane in the test well offgas will be at or below the PEL. 
Excess propane that does not dissolve in the supply water will be deentrained in the surge tank. At a $40 \mathrm{gal} / \mathrm{min}$ water flow rate (maximum anticipated.), up to $0.27 \mathrm{~L} / \mathrm{hr}(0.07 \mathrm{gal} / \mathrm{hr}$, or $0.001 \mathrm{gal} / \mathrm{min})$ of propane could potentially accumulate in the surge tank, assuming that propane is injected at the rate required to obtain a $1.6 \times 10^{-6} \mathrm{~mol} / \mathrm{L}$ concentration in the water with a $90 \%$ dissolution. The surge tank will be connected to the building exhaust system to remove any excess propane from the airspace within the tank. The airspace within the surge tank will be periodically monitored using a portable combustible gas meter to ensure that propane concentrations in the tank remain below $15 \%$ of the LEL.

A maximum of one 5-gal canister of compressed propane will be present at the $306 \mathrm{E}$ Laboratory test location for purposes of performing these tests at any given time. All storage, handling, and use of propane will be in accordance with the standards set forth in Title 29, Part 1910.110 of the Code of Federal Regulations (29 CFR 1910.110) for 1iquified petroleum gases. Requirements of 29 CFR 1910.110 include the following:

- $\quad$ Specified piping and fittings

- Container standards

- Proper marking and identification of storage containers.

Personnel working with the propane will wear goggles for eye protection and gloves to prevent frostbite.

The test setup is a closed system with no direct connection to the sewer system. Prior to disposal of the water to the sewer system, propane concentrations shall be below 100 ppm (approximately 1\% of LEL).

\subsection{QUALITY ASSURANCE}

The activities described in this test plan have been determined to be impact level $Q S$ activities. The following quality assurance requirements are consistent with. this determination.

\subsection{WITNESSING OF TESTS}

Quality assurance witness is not required for any of the test activities described in this test plan.

\subsection{INSTRUMENT CALIBRATIONS}

All instrumentation used for the test activities described in this test plan shall be calibrated in accordance with manufacturer's specifications or WHC procedures prior to use or shall be calibrated by the manufacturer prior to receipt. 
WHC-SD-EN-TP-043, Rev. 0.

\section{3 ' LICENSING REQUIREMENTS}

No licensing requirements are applicable to the activities described in this test plan.

\subsection{ORGANIZATION AND FUNCTION RESPONSIBILITIES}

The organizations responsible for conducting Stanford In-Well Vapor Stripping System test activities are described below.

\subsection{E LABORATORY ORGANIZATION}

The $306 \mathrm{E}$ Laboratory Organization is responsible for conducting all test activities described in this test plan in accordance with the test procedures provided in Chapter 5.0. The 306E Laboratory is also responsible for the detailed design and fabrication of the Stanford system prototype, the circulation well mockup, and the well packer test bed.

\subsection{WHC GEOSCIENCES}

WHC Geosciences is responsible for the overall direction of the Stanford in-well vapor stripping. system test, including preparation and revision of the test $\mathrm{plan}$, test procedures, and test report.

\subsection{SCHEDULE}

The current schedule for the Stanford In-Well Vapor Stripping System Tests calls for all test activities to be completed by May 18, 1994. The schedule for the individual activities that support this overall completion date is outlined below.

\subsection{DESIGN, PROCURE AND FABRICATE STANFORD LABORATORY TEST SYSTEM}

The test well assembly and all supporting equipment and instrumentation will be designed, procured, and installed by May 11, 1994. These activities are the responsibility of WHC Geosciences and the 306E Laboratory personnel.

\subsection{PERFORM LABORATORY TESTS}

The test activities described in this workplan will be performed by the $306 \mathrm{E}$ Laboratory with oversight from WHC Geosciences during the period from May 11, 1994 to June 30, 1994. 
WHC-SD-EN-TP-043, Rev. 0

\subsection{ANALYZE TEST DATA AND PREPARE REPORT}

Test data will be analyzed and a draft report will be prepared by September 30, 1994.

\subsection{REPORTS}

A written report documenting test activities performed and the results of the tests will be prepared when all testing activities are complete. This test report will be released as a separate WHC Environmental Division supporting document. Copies of as-performed test procedures will be included as an appendix to the final report.

\subsection{REFERENCE}

Gvirtzman and Gorelick, 1992, "The Concept of In-Situ Vapor Stripping for Removing VOCs from Groundwater," Transport in Porous Media, 8:71-92, 1992, Kluwer Academic Publishers, the Netherlands. 
WHC-SD-EN-TP-043, Rev. 0

\section{ATTACHMENT 1: DATA SHEETS}

\subsection{PACKER TEST}

Time test initiated:

Sand Added: ( $(Y / N)$

Recorded Observations:

\begin{tabular}{|c|c|c|}
\hline TIME: & $\begin{array}{c}\text { LEAKAGE OBSERVED } \\
(Y / N)\end{array}$ & REMARKS \\
\hline & & \\
\hline & & \\
\hline & & \\
\hline & & \\
\hline & & \\
\hline & & \\
\hline & & \\
\hline & & \\
\hline & & \\
\hline & & . \\
\hline & & \\
\hline & & \\
\hline & & \\
\hline & . & \\
\hline & & \\
\hline & & \\
\hline & & \\
\hline & & \\
\hline & & \\
\hline
\end{tabular}




\subsection{GENERAL TEST DATA SHEET}

Diffuser Tested:

Date:

General Test Conditions (e.g., simulated aquifer, propane injection, head/lift combinations to be tested):

\subsection{INITIAL CONDITIONS SATISFIED}

Stanford system installed in well mockup? ( $Y / N$ )

Diffuser installed in Stanford system? ( $\mathrm{Y} / \mathrm{N}$ )

All system valves closed? ( $Y / N)$

Main well filled with water to static water level? ( $Y / N$ )

Water, in surge tank equilibrated with well? ( $Y / N)$

(If propane will be used) Ventilation system operating and providing adequate ventilation to the surge tank? ( $Y / N$ )

\subsection{VERIFY INSTRUMENT CALIBRATIONS}

Air Flowmeter calibrations current? ( $Y / N)$

Calibration date:

Equipment serial number

Temperature gauge calibrations current? ( $\mathrm{Y} / \mathrm{N}$ )

Calibration date:

Equipment serial number

Pressure gauge calibrations current? ( $Y / N)$

Calibration date:

Equipment serial number'

Pressure transducer calibrations current? ( $Y$ / N)

Calibration date:

Equipment serial number

Datalogger calibration current? ( $\mathrm{Y} / \mathrm{N})$

Calibration date:

Equipment serial number

Combustible gas meter calibration current? ( $Y / N)$

Calibration date:

Equipment serial number 


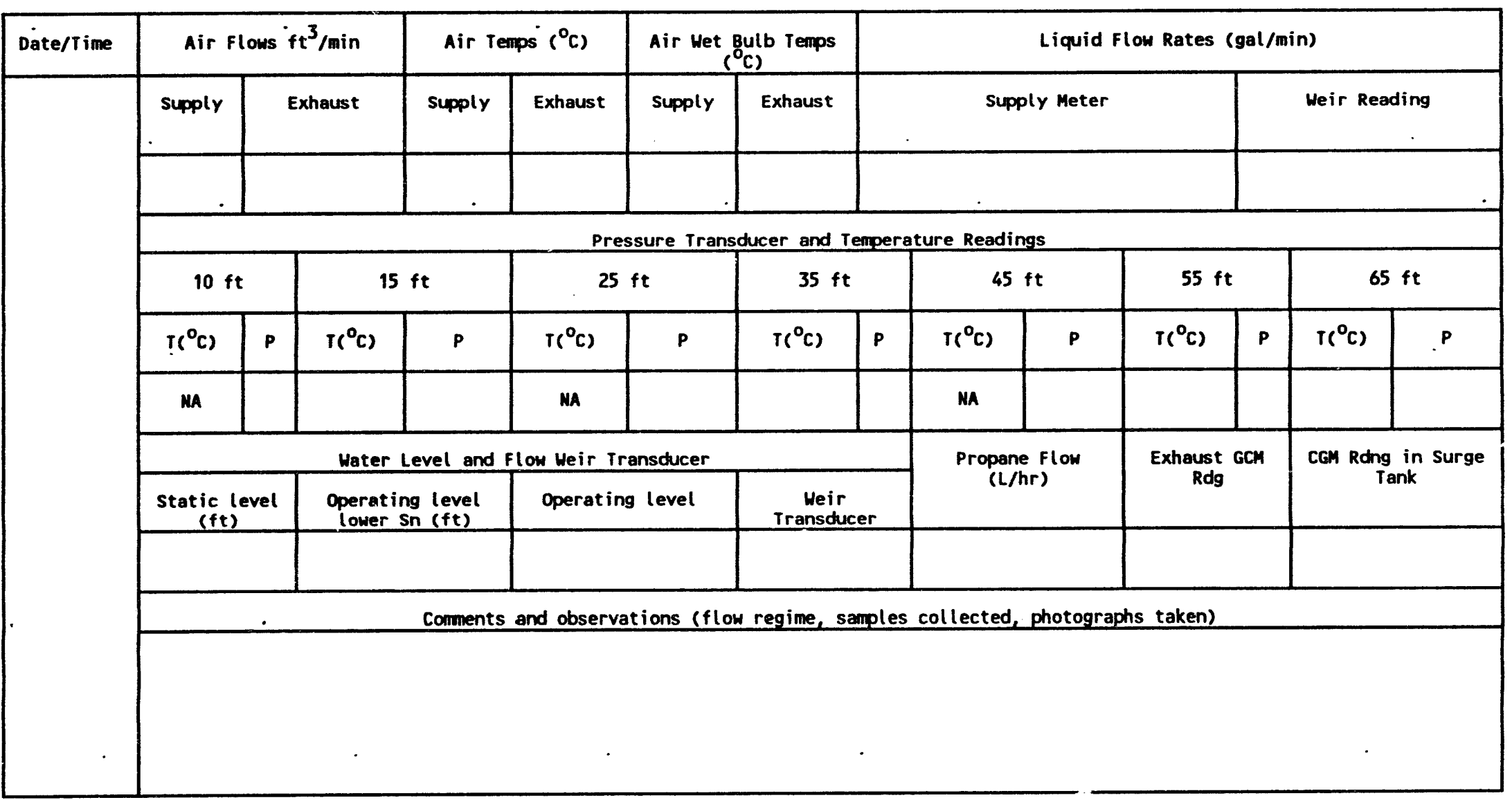



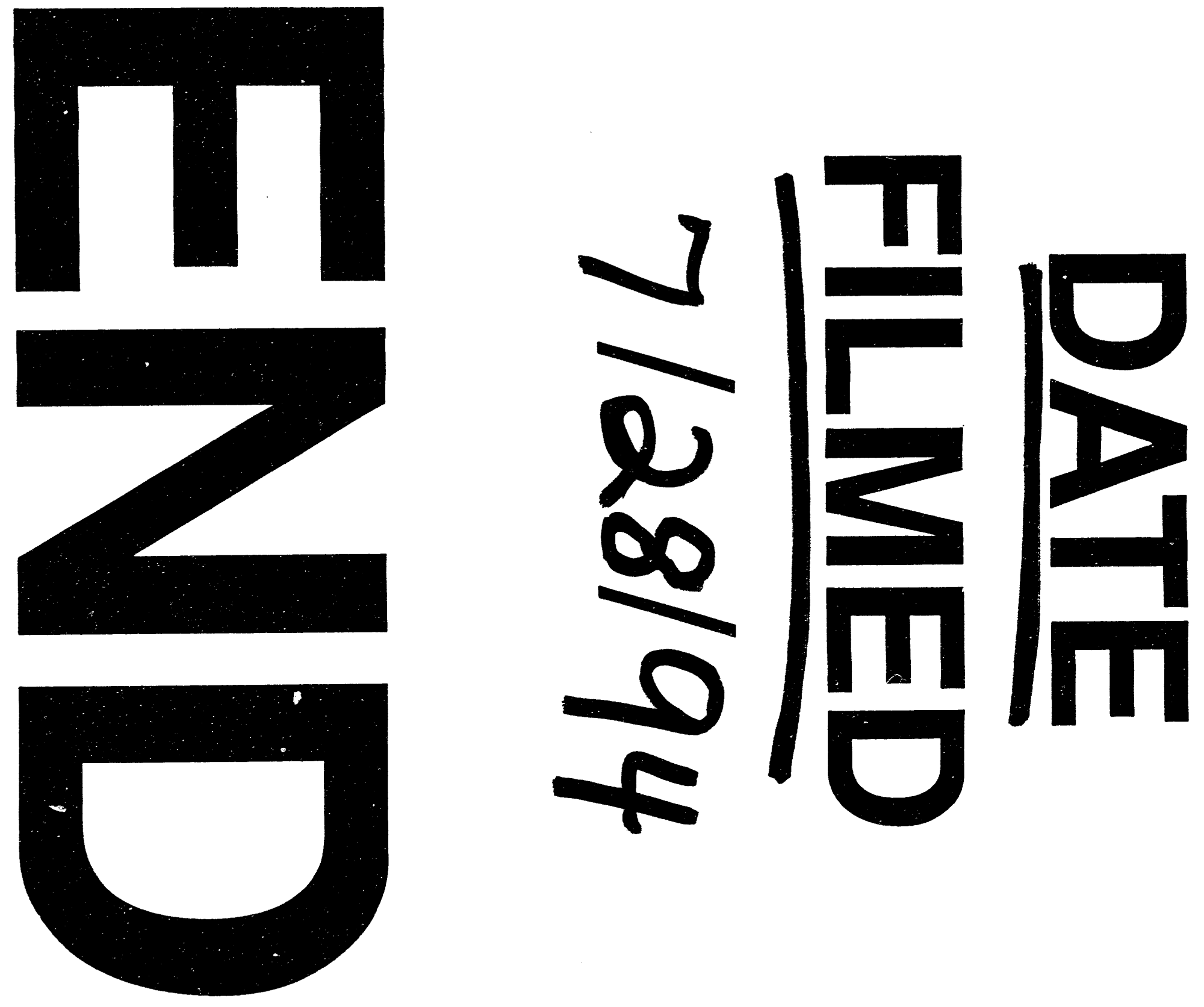


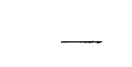

